\title{
Development of educational programs for enhancing financial literacy of Russian citizens
}

\author{
Nadiya M. Sabitova ${ }^{1 \mathrm{a}}$, and Dmitry G. Mueller ${ }^{1}$ \\ ${ }^{1}$ EDP Kazan Federal University, 4, Butlerov st., Kazan, 420012, Russia
}

\begin{abstract}
Currently, the financial literacy is one of the indicators for the level of economic competence in the country. The financial competence of the population should increase with the growth of living standards. But in Russia, the matter of financial literacy has been ignored for years. Not all Russian people are financially competent, even those who have secondaryand university-level degrees. Furthermore, financial literacy requires to be constantly updated, considering dynamic economic processes ongoing both globally and domestically. As late as in recent years, the Russian Government has paid serious attention to this issue. Ministries and authorities undertake to create Internet portals on their official websites that serve to enhance financial literacy of people. The Ministry of Finance was the first that had such portal called "Budget for General Public" on its official website. The Russian Ministry of Industry and Trade undertakes the same activity to produce its own web portal as part of the "Budget for Public" project. This paper covers the overview of this project.
\end{abstract}

Keywords: Financial literacy; national strategy; project; budget for general public; information; polling

\section{Introduction}

Russia is developing its National Strategy of financial education as part of the "Facilitating the increase of financial literacy and growth of financial education in the Russian Federation" project [3]. This activity was started back in 2011; the key coordinator is the Russian Federation Ministry of Finance. As the liberalisation of the national policy was limited in 2008-2012, this was a prerequisite for this job. Particularly, it resulted in a Public Government Institute established in 2012, one of the focus areas of which is to ensure budget information transparency of the Russian Federation budget system. Now, other federal ministries have joined to this job. The RF Ministry of Industry and Trade is, among others, one of the key authorities of the country, which backs individual priority industry sectors of Russia. Every ministry is in the process of designing its own "Budget for Public" portals under this project. The objective of these portals is to not only enhance the

\footnotetext{
${ }^{a}$ Corresponding author: chulpan212@mail.ru
} 
financial literacy, but also provide transparency in budgetary process, information awareness in both the budgeting and using budget funds, as well as their monitoring. Budget transparency is a requirement of the fiscal legislation of Russia and international organisations, including the International Monetary Fund. The matter of budget transparency relates to all Russian ministries and departments. Alongside with that, the compliance of information on budget with the needs of different groups of people is an essential condition of demand for such data by the society. In this regard, important is the study of concerns related to how the national budgetary policy is implemented. This paper provides with the results of 2015 survey targeting the information awareness of people about the budget figures of the RF Ministry of Industry and Trade that were used to form the basis of "Budget for Public" portal.

\section{Materials and methods}

Many countries use computer technologies as the most accessible tool to facilitate the people in terms of financial awareness. Russia is among them. It is also important to develop the interest of people in financial information, which may be accessible on the official websites of various governmental and municipal institutions. The people do not always clearly understand this information due to its quality being specific. Therefore, it is essential that the information would not only be accessible, but also clear for a person having no financial skills. Additionally, the content of such resources should respond to their concerns of national budgetary policy.

The residents of major cities of Russia aged from 16 to 70 were asked at the stage of pre-designing the "Budget for Public" project of the RF Ministry of Industry and Trade. According to the RF Federal Statistics Service data, the number of this group of people amounted to 80.2 million persons in 2014 . 1410 respondents were surveyed.

Table 1. Distribution of respondents by cities

\begin{tabular}{clc}
\hline Ref. & \multicolumn{1}{c}{ City } & Number of respondents \\
\hline 1. & Moscow & 588 \\
2. & Saint-Petersburg & 238 \\
3. & Nizhny Novgorod & 60 \\
4. & Kazan & 60 \\
5. & Perm & 49 \\
6. & Samara & 56 \\
7. & Rostov-on-Don & 56 \\
8. & Ufa & 59 \\
9. & Omsk & 56 \\
10. & Chelyabinsk & 56 \\
11. & Novosibirsk & 70 \\
12. & Irkutsk & 32 \\
13. & Vladivostok & 30 \\
& TOTAL: & $\mathbf{1 4 1 0}$ \\
\hline
\end{tabular}

The survey shows the information awareness level and concerns of the people from different regions of Russia concerning how the budget of the Ministry of Industry and Trade is built and its funds are used. In addition, the one of the survey objectives was to reveal the concerns of the people towards the Ministry's budget.

\section{Theory}

The educational process does not end up with secondary-level and even university-level degree. It must continue, specifically, in current situation, when the "ageing" of knowledge accelerates, this process also raises the need for new learning that we not always can 
challenge unassisted. This primarily applies to what we call financial literacy. Therefore, this movement in education of the population should be supported by governmental authorities through different programs, including, but not limited to general education schools, also in specialised secondary school and higher education establishments. Many countries are concerned about the matter of financial literacy in a rapidly growing scope of financial services, new financial products and instruments as stipulated in the High-Level Principles on National Strategies for Financial Education approved by the G20 leaders in June 2012 [9]. This document has been produced in liaison with the Organisation for Economic Cooperation and Development (OECD) and the International Network of Financial Education (INFE) for coordination of financial education development in different countries and its adjustment to the requirements of particular countries. Currently, known is a number of publications covering the financial literacy issues in different countries $[2,5,6,8,10,11]$, information awareness of people being consumer of financial services related to their liabilities, risks and capabilities $[1,4,7]$

\section{Results and discussion}

It is usual with Russian ministries to be criticised that their activity is not transparent and the people have no chance to get acquainted with their performance, scope and structure of financing, services they render to the people and so forth. The RF Ministry of Industry and Trade is not an exception in this regard. The current official website of the Ministry provides insufficient information to facilitate people's concerns. Considering the strategic importance of growing the country's industry as a basis of the entire economy, the developers of this project proceeded from the premise that the people should primarily know the following:

- Priority industries the Russian Government backs through the budget of this Ministry;

- Budgetary expenditure structure of this Ministry;

- The way the federal programs of backing industry and trade are generated;

- The share of administrative costs the Ministry spends for itself and other issues.

The surveys show a relatively low level of information awareness towards both the performance of the Ministry and its budget. Only $13 \%$ of respondents were aware of the project "Budget for Public" (Chart 1). The majority of the respondents (64\%) are not aware of the performance of the Ministry of Industry and Trade (Chart 2).
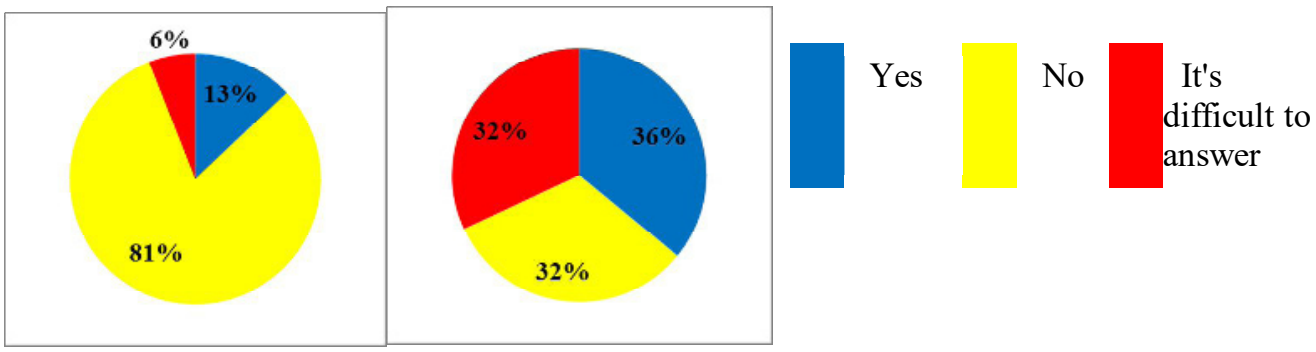

Chart 1. Results based on response alternatives

Chart 2. Results based on response alternatives

Highly interesting are concerns of the people with respect to the budget of this Ministry. Only $25 \%$ of respondents expressed their interest in this information, $38 \%$ of respondents found it less interesting, while $17 \%$ of respondents showed no interest (Chart 3). At the same time, $54 \%$ of respondents are interested, $25 \%$ of respondents are less interested and $11 \%$ of respondents are not interested at all in priorities when sharing the federal budget expenditures. 


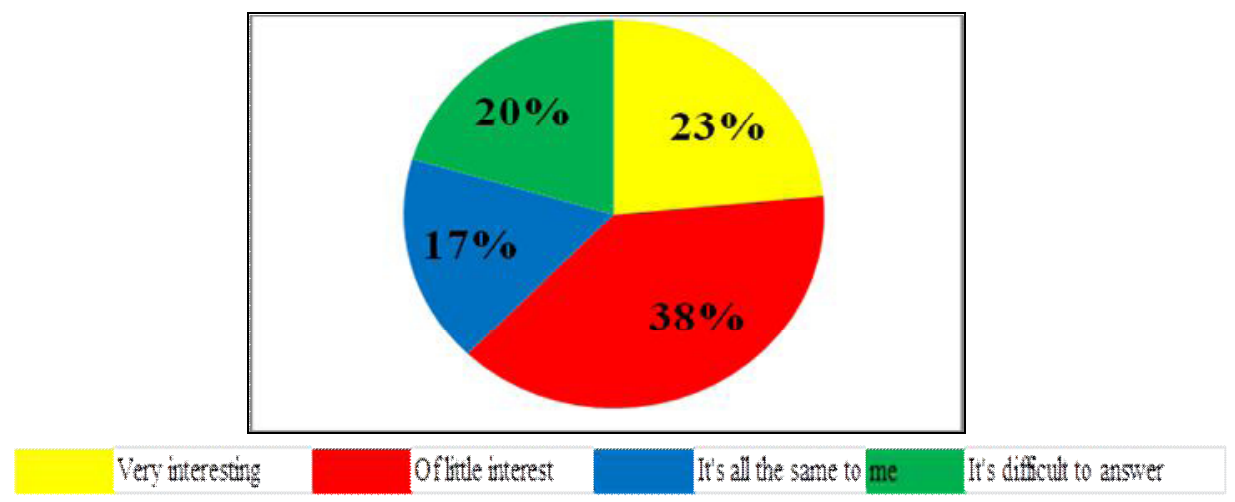

Chart 3. Results based on response alternatives

The respondents were given several alternatives to pick: $55 \%$ of respondents set much store by development of present-day productions in Russia, 7\% of respondents - creating new jobs and $23 \%$ of respondents indicated import phase-out and other focus areas. $55 \%$ of respondents showed their interests in Russian defence industry, $31 \%$ of respondents considered this matter less interesting, 5\% of respondent felt no interest and $9 \%$ were undecided. As the Russian federal budget highly relies on oil and gas revenues, the people were asked about what they think to reduce such reliance. The majority of the respondents $(69 \%)$ showed their interests, $16 \%$ of respondents considered this matter less interesting and $15 \%$ were undecided. The concerns of respondents towards the national programs introduced by the Ministry of Industry and Trade are distributed in an erratic manner. The respondents showed their highest concern in medical and pharmaceutical industries as well as in competitive growth of Russian industry (55\% and 53\% respectively). At the same time, the respondents showed their interest in state regulation of consumer market prices: $77 \%$ of respondents considered it interesting and $23 \%$ were undecided.

\section{Conclusion}

Following the survey results, the developers of the "Budget for Public" project from the Ministry of Industry and Trade succeeded to solve two problems: Identify the level of information awareness regarding the Ministry's performance and questions of the day towards its budget. The survey revealed that people had less information on both the performance and the budget. This supports the urgency of enhancing financial literacy of Russian residents. Therefore, the project of the RF Ministry of Industry and Trade to develop a website portal is actual and will be in demand after it is introduced. The goal for the project developers is to make it simple and accessible for people. Furthermore, the survey findings show that the Ministry did not sufficiently focus on liaison with the public, provide accessibility and transparency of information and its performance. As for the more actual and important concerns of the people, these refer to priorities in growth of industries associated with profitable investments made by the Ministry in individual projects. People understand that they feed the Ministry's budget by paying taxes in good faith and want to know how they are spent. Moreover, the project developers arrived at a conclusion that the information should be accessible to the residents and interesting in content using nonstandard approaches and technologies able to catch the interest of targeted audience. 


\section{References}

1. Ardic O. P., Chen G. \& Alexia Latortue, An Overview of the Supply-Side Data Landscape. CGAP and International Finance Corporation, Washington, DC. Retrieved from http://www.cgap.org/sites/default/files/CGAP-Forum-Financial-Access-2011-AnOverview-of-the-Supply-Side-Data-Landscape-Jun-2012.pdf, (2011).

2. Atkinson, A. \& F. Messy, Measuring Financial Literacy: Results of the OECD. International Network on Financial Education (INFE) Pilot Study. OECD Working Papers on Finance, Insurance and Private Pensions, (15), OECD Publishing. Retrieved from http://dx.doi.org/10.1787/5k9csfs90fr4-en, (2012).

3. Facilitating the increase of financial literacy and growth of financial education in the Russian Federation. (n.d.) Retrieved April 25, 2015, from The RF Ministry of Finance, http://www.minfin.ru/ru/om/fingram/index.php

4. FINRA, Financial Capability in the United States: Report of Findings from the 2012 National Financial Capability Study. Retrieved from http://www.usfinancialcapability.org/downloads/NFCS_2012_Report_Natl_Findings.p df, (2013).

5. García, N., A. Grifoni, J. López \& D. Mejía., Financial Education in Latin America and the Caribbean: Rationale. Overview and Way Forward\|. OECD Working Papers on Finance, Insurance and Private Pensions, (2013).

6. Grifoni, A. \& F. Messy., Current Status of National Strategies for Financial Education: A Comparative Analysis and Relevant Practices. OECD Working Papers on Finance, Insurance and Private Pensions. (16), OECD Publishing. doi: 10.1787/5k9bcwct7xmnen, (2012).

7. Money Advice Service - The Financial Capability of the UK (n.d.). Retrived May, 5, 2015, from http://www.lautorite.qc.ca/files/pdf/educationfinanciere/thefinancialcapabilityuk.pdf

8. OECD/INFE, Set of Criteria, Principles, Guidelines and Policy Guidance to Improve Financial Education Part 3: Measurement and Evaluation Tools. Retrieved from /http://responsiblefinance.worldbank.org/ /media/GIAWB/FL/Documents/Publications /oecdinfe-set-of-criteria-principles-guidelines-and-policy-guidance-to-improvefinancial-education-part-2-addressing-youths-and-womens-needs-for-financ.pdf, (2013).

9. Perfection of National Strategies for Financial Education, Retrieived April 15, 2015, from A joint publication of Russian Federation presidency in G20 and OECD, http://ippk.arkh-edu.ru/web_community/financial/1.\%20G20_OECD_final\%20RU.pdf, (2013).

10. Romagnoli A. \& Trifilidis M., Does financial education at school work? Evidence from Italy. Occasional Papers (Questioni di Economia e Finanza), (155), Bank of Italy Publishing. Retrieved from http://www.bancaditalia.it/pubblicazioni/econo/quest_ecofin_2/qef155/QEF_155.pdf, (2013).

11. Shareholder and Corporate Responsibility Review 2011. Retrived from http://www.anz.com/resources/a/a/aaelb4004919afbfa777f7fc8cff90cd/2011-CRReview.pdf?MOD=AJPERES 